\title{
Descrpition The Low Utilization of Maternity Waiting Home
}

\author{
Rida Mustasmara 1 , Muhammad Ardian C.L ${ }_{1}$, Endyka Erye Frety 1 \\ ${ }^{1}$ Department of Midwifery Education, Faculty of Medicine University Airlangga 60132, Surabaya, East Java, Indonesia \\ Email : rida.mustasmara-2020@fk.unair.ac.id
}

\begin{abstract}
Background WHO has recommended the Maternity Waiting Home (MWH) as one of the interventions to improve maternity care. Women who do not have access to health facilities because of the constraints posed by distance, they can benefit from living in a Maternity Waiting Home (MWH) and being closer to the facility can manage emergency obstetric complications. However, the facts on the ground that pregnant women and the community do not want to wait for the delivery process at the maternity waiting home, they prefer to wait at home alone if there are signs of labor they choose to come directly to the Public health center. In addition, there are also pregnant women who do not want to go to health facilities, preferring to call a shaman to assist with the delivery process. This study aims to describe the use of maternity waiting homes in an area in Indonesia. This research method is a descriptive survey using a questionnaire on 47 pregnant women respondents. The data is presented in the form of a frequency distribution table for the planned use of the maternity waiting home by pregnant women. The results of this study indicate that only $25.4 \%$ of pregnant women respondents plan to use the maternity waiting home and $74.6 \%$ do not plan to use the maternity waiting home.
\end{abstract}

Keywords: Pregnant women, Utilization, Maternity waiting home

\section{Introduction}

Indonesia still faces gaps in access to health services and difficulties in reducing the MMR (Maternal Mortality Rate). The 2015 Demographic and Health Survey (IDHS) showed that MMR in Indonesia reached 305 deaths per 100,000 live births (Ministry of Health, 2016). Data on maternal mortality in West Papua Province in 2017 was 218 cases of death or 836 per 100,000 live births and in 2018 there were 184 cases of death or 848 per 100,000 live births (West Papua Health Profile 2018). As for Fakfak Regency, the 2020 Health Profile explains that, in 2019 the number of maternal deaths was 2 cases or 13.59 per 10,000 live births and the number of infant deaths was 9 cases or 6.1 per 1,000 live births (Fakfak Regency Health Profile in 2020).

The high maternal mortality rate illustrates the low level of health services for pregnant women and mothers giving birth. Data on delivery services obtained in 2019 amounted to $90.95 \%$ of deliveries assisted by health workers in health care facilities of $88.75 \%$. Thus, there are still around $2.2 \%$ of deliveries that are assisted by health workers but are not carried out in health care facilities.

Utilization of health services according from Notoatmodjo (2012), is the behavior of individuals and groups to perform or seek treatment. The consumer's decision to use or utilize health service facilities is inseparable from the behavior possessed by each individual and the factors that influence it (Notoatmodjo, 2012). There are three theories regarding behavior in health sciences put forward by experts, namely Anderson's (1975) theory of behavioral model of health services utilization, Lawrence Green's (1980) theory of community behavior model and Dever's (1984) theory. regarding the utilization of health services. From the three theories, the framework for the utilization of health services is summarized, namely the birth waiting 
house service which consists of variables which are factors related to the use of the birth waiting house and the obstacles in the use of the birth waiting house (Andersen, $R$ and Newman, 2005).

WHO has recommended Maternity Waiting Home (MWH) as one of the interventions to improve maternity care. Women who do not have access to health facilities because of the constraints posed by distance, they can benefit from living in Maternity Waiting Home (MWH) and being closer to the facility can manage emergency obstetric complications (WHO, 1996). However, the facts on the ground that pregnant women and the community do not want to wait for the delivery process at the maternity waiting home, they prefer to wait at home alone if there are signs of labor they choose to come directly to the Puskesmas. In addition, there are also pregnant women who do not want to go to health facilities, preferring to call a traditional healer to assist in the delivery process (Hasby et al., 2018).

The Maternity Waiting Home in Fakfak Regency has been established since 2017, but until now the utilization of the Maternity Waiting Home in Fakfak Regency is classified very low. Data for 2020 were obtained from 3 (three) Health Centers located in the urban area of Fakfak Regency where from the three public health center have Maternity Waiting Home (MWH) in their fostered work areas, each of which has a percentage of utilization of Maternity Waiting Home (MWH) in the working area of the Sekban Health Center $(0.09 \%)$, the Maternity Waiting Home (MWH) in the Fakfak City Health Center target area $(0.07 \%)$ and the Maternity Waiting Home (MWH) in the Fakfak Tengah Health Center target area (0.06\%) (District Health Office Fakfak, 2021).

\section{Method}

This research was conducted in the working area of the Central Fakfak Health Center, Fakfak Regency, West Papua. The design of this research is descriptive by conducting a survey. The population in this study were pregnant women who received health services at the Fakfak Tengah Health Center, Fakfak Regency, West Papua. With the inclusion criteria is pregnant women who received health services at the Fakfak Tengah Health Center at the time the researcher conducted the study and were willing to become respondents. The sampling technique was non-probability sampling with purposive sampling technique. The number of respondents obtained during the study were 67 pregnant women. Primary data in this research was obtained through a survey by giving a questionnaire to pregnant women. While secondary data was obtained from the Fakfak District Health Office, data from the KIA/KB Room at the Fakfak Tengah Health Center, data from the Maternity Room at the Fakfak Tengah Health Center and data from the Maternity Waiting Home (MWH) in the working area of the Fakfak Tengah Health Center, Fakfak Regency, West Papua.

\section{Result}

The secondary data obtained from 3 (three) Maternity Waiting Home (MWH) in the urban area of Fakfak Regency, West Papua Province have a percentage of the utilization of Maternity Waiting Home (MWH) are Maternity Waiting Home (MWH) in the working area of the Sekban Health Center $(0.09 \%)$, Maternity Waiting Home (MWH) in the area of Fakfak City Health Center $(0.07 \%)$ and Maternity Waiting Home (MWH) in the target area of Central Fakfak Health Center (0.06\%) (Fakfak District Health Office, 2021).

Maternity Waiting Home (MWH) in the working area of the Fakfak Tengah Health Center which is the Maternity Waiting Home (MWH) with the lowest utilization in the urban area of Fakfak Regency. Then an assessment was carried out using a questionnaire on pregnant women, so that the results of the frequency distribution of the planned use of the maternity waiting home in the work area of the Fakfak Tengah Health Center were carried out, as follows : 
Table 1: Frequency distribution of Planned Use of Maternity Waiting Home.

\begin{tabular}{lcc}
\hline \multicolumn{1}{c}{$\begin{array}{c}\text { Utilization Plan of Maternity Waiting Home } \\
(\mathrm{MWH})\end{array}$} & Amount (n) & Percentage (\%) \\
\hline $\begin{array}{l}\text { Have a plan to utilize the Maternity Waiting Home } \\
(\mathrm{MWH})\end{array}$ & 17 & 25.4 \\
$\begin{array}{l}\text { Do not have a plan to utilize the Maternity Waiting } \\
\text { Home (MWH) } \quad \text { Total }\end{array}$ & 50 & 74.6 \\
\end{tabular}

The table above shows that most respondents do not have a plan to utilize the maternity waiting home, as many as 50 respondents $(74.6 \%)$.

\section{Discussion}

Maternity Waiting Home is a place or room located near a health facility (Hospital, Public health center, Village health center) that can be used as a temporary residence for pregnant women and their companions (husband/cadre/shaman or family) for several days, while waiting for delivery to arrive. and a few days after giving birth. As a form of community-based health efforts, in the form of a place (a separate house/building) that can be used as a temporary residence for pregnant women who will give birth to postpartum, including the baby they are born with and their companions (husband/family/health cadres) ( Indonesian Ministry of Health, 2019).

The Maternity Waiting Home is one of the health service facilities provided by the government to help expand and increase the scope of deliveries assisted by health workers and carried out in health facilities in order to reduce maternal and infant mortality. According to Permenkes Number 82 of 2015, the objectives of the Maternity Waiting Home are: 1) increasing access to health services for pregnant, maternity and postpartum women and newborns, 2) increasing the number of deliveries in health care facilities, and 3) reducing cases of complications in pregnant women. , maternity and newborns (Permenkes RI, 2015).

The low utilization of the maternity waiting home or the absence of an increase in the use of the maternity waiting home are things that need to be improved and the problem is why these facilities are not used properly in an area. In Fakfak Regency, maternity waiting home have existed for the last 4 (four) years, but their utilization is still very low. Even though the scope of the work area of the public health center in every district in Fakfak Regency, West Papua is very wide. For example, the Central Fakfak Health Center has a working area of $705 \mathrm{~km} 2$ which oversees 14 villages and 1 ward, consisting of 20 Rt (neighborhood association) with a total population of 11,850 inhabitants in 2020 data. In addition, the travel time to health facilities from each village and sub-district also varies. In this case, the travel time to the first health service facility, example is the Fakfak Tengah health center, is the fastest 5-10 minutes (for the villages/ward of Kayu Merah, Katemba, Nemiwikarya, etc.) and the longest 45-60 minutes (for the villages/ward of Pirma, Pasir Putih, Sakartemen and Mandopma) (Central Fakfak District in Figures, 2019).

The results of the research conducted at the Fakfak Tengah Health Center which is the health center with the lowest coverage the utilization of maternity waiting home in urban areas, Fakfak Regency, West Papua, it was found that most of the $50(74.6 \%)$ pregnant women respondents did not plan to use the maternity waiting home in the area of work under the guidance of the Central Fakfak Health Center. The reasons respondents did not plan to use the maternity waiting home were mostly due to not knowing the existence of the maternity waiting home (44.8\%), the distance from the house was close $(50.7 \%)$, feeling able to directly access health facilities such as health centers and hospitals even though the respondent's house was far away from health 
facilities (23.9\%), assumes that the delivery will be safe so that it does not require additional needs especially for mothers who are multigravida (40.3\%), have never heard of the existence of the maternity waiting home either from their families or from community leaders in their village (71.6\%), and never received support from health workers, either information or directions to use the maternity waiting home $(68.7 \%$.

Several other research that examined the variables related to the use of maternity waiting home, by Riszka Savitry Harahap (2018) in the work area of the Binjai Serbangan Health Center, Asahan Regency, showed that there was an influence between mother's knowledge on the use of Maternity Waiting Home (MWH). The researcher stated that knowledge about the importance of utilizing the Maternity Waiting Home (MWH) will make a pregnant woman who will give birth first use the existing Maternity Waiting Home (MWH) (Harahap, 2018).

Regarding maternal parity, research conducted by Harahap (2018) at the Binjai Health Center, Asahan Regency which shows that maternal parity has a relationship with the use of the Maternity Waiting Home (MWH) where there is a mother's perception of the importance of using Maternity Waiting Home (MWH) when giving birth which is not so important (Ni'matul, 2020).

Regarding distance, the results of a study conducted by Sukoco in 2015 in West Southeast Maluku showed that the distance to the Maternity Waiting Home (MWH) was related to the use of the Maternity Waiting Home (MWH), where respondents lived $25 \mathrm{~km}$ (Sukoco, 2015). As well as other studies that are in line, namely research conducted in Timor Leste by Wild K in 2012, that there was an increase in the use of Maternity Waiting Home (MWH) in communities less than $5 \mathrm{~km}$ and $6-25 \mathrm{~km}$ from health facilities, while in communities $>25 \mathrm{~km}$ tended to do not use Maternity Waiting Home (MWH) (Wild K, et al., 2012).

Regarding the role of community leaders, research conducted by Harahap (2018) which states that the support from community leaders is one of the benchmarks for mothers who will use Maternity Waiting Home (MWH) because a figure has a great influence in moving the wider community, because the general public is easier to accept what is happening, described by their role models. And the results of research conducted by Harahap, et al (2018) regarding the role of health workers explained that there was a relationship between the support of public health center officers and the use of maternity waiting home in the work area of the Binjai Serbangan Health Center, Asahan Regency (Harahap, 2018). Another similar study is the research conducted by Nakua (2015) in Ghana which explains that the attitude of the helper in this case the health worker influences the mother in choosing where and by whom to give birth (Nakua, et al., 2015).

\section{Conclusion}

Hoped that the low utilization of the maternity waiting home can be improved by focusing on the problems causing the low utilization by the community and the best solutions related to the services most needed by the community in an area, especially the people of Fakfak Regency, West Papua. In addition, public awareness and activeness of the existence of government health service facilities must also be increased. This can be realized by the existence of activeness and better attention from the government, health workers and community leaders to socialize the existence of these facilities so as to help fulfill the purpose of the existence of the maternity waiting home.

\section{Acknowledgements}

Thank to the head of the public health center, the midwife in charge of the maternity waiting home and other health workers who have given permission and assisted the researcher during the conduct of the study as well as pregnant women who have participated in this study. 


\section{References}

Andersen, R., \& Newman, J. F. (2005). Societal and individual determinants of medical care utilization in the United States. Milbank Quarterly, 83(4), 1-28.

Atika, T. (2018). Faktor-faktor Yang Mempengaruhi Pemanfaatan Rumah Tunggu Kelahiran Oleh Ibu Bersalin Di Puskesmas Kabupaten Aceh Timur Tahun 2018. Tesis. Universitas Sumatra Utara.

Badan Pusat Statistik Kabupaten Fakfak. (2019). Distrik Fakfak Tengah Dalam Angka 2019. Fakfak : Katalog BPS Kabupaten Fakfak.

García Prado, A., \& Cortez, R. (2012). Maternity waiting homes and institutional birth in Nicaragua: Policy options and strategic implications. International Journal of Health Planning and Management, 27(2), 150-166.

Gborgbortsi, W. D., Dwomoh, D., Alegana, V., Hill, A., Tatem, A. J., \& Wright J. (2020). The Influence of Distance and Quality on Utilisation of Birthing Services at Health Facilities in Eastern Region, Ghana. BMJ Global Health, 4.

Harianis, S., Kebidanan, A., \& Gemilang, H. (2020). Keritang Sandra Harianis Analysis Of Imlementation Of Birth Waiting House In The Work Area Of The Kotabaru Community Health Centre , Keritang Sub District. 10(2), 266-281.

Hong, R., \& Them, R. (2015). Inequality in access to health care in Cambodia: Socioeconomically disadvantaged women giving birth at home assisted by unskilled birth attendants. Asia-Pacific Journal of Public Health, 27(2), NP1039-NP1049.

Hasby, A. R., Fadilah, D., \& Putri, A. (2018). DAERAH TERPENCIL DI KABUPATEN SUMBAWA A. Pendahuluan Salah satu tujuan $S D G$ 's menurunkan AKI ( Angka Kematian Ibu) dan AKB ( Angka Kematian Bayi ) yaitu menjamin kehidupan yang sehat dan ( Sustainable Development Goals ) dalam mendorong kesejahteraan b. 34-47.

Kementerian Kesehatan Republik Indonesia. (2020). Buku Pedoman Pelaksanaan Program KIA Revisi Tahun 2020. Jakarta : Kementerian Kesehatan RI.2021

Notoatmodjo, S. (2012). Metodologi Penelitian Kesehatan. Jakarta: PT Rineka Cipta.

Permenkes 65 tahun. (2015). Berita Negara. Menteri Kesehatan Republik Indonesia Peraturan Menteri Kesehatan Republik Indonesia, Nomor 65(879), 2004-2006.

Profil Kesehatan Provinsi Papua Barat Tahun 2018

Profil Kesehatan Kabupaten Fakfak Tahun 2019

Profil Kesehatan Kabuapten Fakfak Tahun 2020

Profil Puskesmas Fakfak Tengah Tahun 2021

Sukoco, N. E. W. (2018). Kajian Keberlangsungan Rumah Tunggu Kelahiran (RTK) Dalam Upaya Menurunkan Angka Kematian Maternal DI Indonesia : Study of Sustainability of Maternity Waiting Home ( MWH ) in Efforts to Reduce Maternal Mortality Rate in Indonesia. Buletin Penelitian Kesehatan, 21(2), 114-124.

Sukoco, N. E. W., \& Suparmi, S. (2017). Pemanfaatan Rumah Tunggu Kelahiran di Puskesmas Adaut Kecamatan Selaru Kabupaten Maluku Tenggara Barat Tahun 2015. Buletin Penelitian Kesehatan, 45(1), 65-72.

Wild K, Barclay L, Kelly P, and Martins N. (2012). The tyranny of distance: maternity waiting homes access to birthing facilities in rural Timor-Leste. Bull World Health Organ.;90:97-103.

Ulumiah Ni'matul. (2020). Faktor-faktor yang berhubungan dengan Pemanfaatan Rumah Tunggu Kelahiran (RTK) Tengaran Tahun 2019. Skripsi. Universitas Negeri Semarang. 